\title{
Development Rooted on Riojan Soil: The Wine Cluster and Beyond
}

\author{
Mikel Larreina*, Fernando Gómez-Bezares and Ricardo Aguado
}

Universidad de Deusto, La Comercial, Avenida de las Universidades 24, 48007, Bilbao, Spain

\begin{abstract}
The wine industry has experienced dramatic changes since the 80's. The surge of New Producing Countries challenging the Euro-centred status quo, the decline of consumption in traditional markets, the permanent large imbalances in the sector resulting in global overproduction, the apparition of new consumers, the development of wine tourism... In this period of time, Rioja, a region producing wines since the Middle Ages, has been able to use all its strengths to increase its market share in the wine global market, driving the regional economy to higher and more widespread social welfare.

This paper shows the main features of this relation between wine and territory at Rioja, and the reasons for the successful performance of this sector, using a number of approaches (cluster, agro-industrial district, oenopolis) that progressively enlarge the scope of the analysis up to including all potential relations between the main regional sector and the society itself.
\end{abstract}

Keywords: Wine cluster, Rioja region, regional development, agro-industrial district, oenopolis.

\section{INTRODUCTION: WINE AS A DRIVING FORCE FOR REGIONAL DEVELOPMENT}

Wine has played a major role in Mediterranean societies since the Ancient Ages and quite likely even during the late prehistoric times; in fact, there are proofs of the existence of viticulture around $6000 \mathrm{BC}$, even though grapes were collected and consumed since 30000 BC. The role of viticulture and wine-making has been much greater than merely eating fruit and drinking wine. On one hand, it has shown great relevance in several religions, being a sacred drink full of symbolism. We can cite Noah, who inmediatly after leaving the Ark planted a vine; or the myths of wine being given by Gods as a gift to mankind; or the ceremonial role played by wine in Egypt, where it was a necessary complement for the afterlife, and buried in tombs for this purpose; or the games that honoured Dyonisus in Greece, in which people feasted and enjoyed the pleasures of life; or even the role of wine in the Last Supper, where it is linked by Jesus himself to his own blood. Besides religion, wine had an important economic role $[1,2]$ : it was a product traded between different nations; it was a main industry in some regions, and its origin even served to identify the product; it was a product for which specific regulation was produced, since some rules on wine were included in the first legal code kept to date, the Hammurabi code (dated around $1750 \mathrm{BC})$; and it was a product chosen for investment by educated investors, as Roman wealthy families did. Measures to protect local industries were even experienced at that time; for instance, when the emperor Domitianus tried

*Address correspondence to this author at the Universidad de Deusto, La Comercial, Bilbao, Spain; Tel: (+34) 9441392 60, Ext. 2460; Fax: (+34) 94 44573 81; E-mail: mlarrein@com.deusto.es to control an excessive area under vines ${ }^{1}$ and decided to forbide anyone to plant more vines in Italy, ordering simultaneously to cut down vineyards in the provinces (or, at most, leave them halved), hence favouring the italian industry.

The role of wine production in the Middle Ages and the Modern era was determinant for some regions, mainly in the Mediterranean basin [2]; for instance, as late as 1878, the Spanish Government wrote that "the wine sector's performance affects the national wealth, and hence the

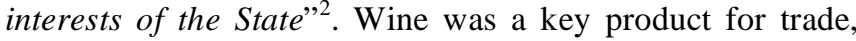
being affected by most changes in trading rules; hence, some monopolistic companies controlling the wine commerce were founded (as the Company for High Douro, in 1756) and wine was included among the products to be protected by the Apellations d'Origine when the first international Agreements in this field were signed in the XIX century. The impulse to economic studies during the Enlightenment produced a number of works studying in some way the wine market; for instance, the great economist Adam Smith wondered on the reasons for the French king Louis XV's interdiction for new planting of vineyards. Furthermore, David Ricardo used wine to explain the comparative advantages of regions and nations, and to show the social welfare linked to trade; his classical example was

\footnotetext{
${ }^{1}$ The decision taken by Domitianus for the whole Roman Empire in $92 \mathrm{AD}$
may be seen as well as a precedent of much more recent European CMO's

${ }^{1}$ The decision taken by Domitianus for the whole Roman Empire in $92 \mathrm{AD}$
may be seen as well as a precedent of much more recent European CMO's rules, oriented towards reducing the productive potential and controlling the wine supply.

${ }^{2}$ This is an approximate translation from the Spanish. The original reads like this: "Afectaría la pérdida de esta riqueza vitivinícola [...] a la riqueza pública, y por lo tanto a los intereses del Estado". Extracted from an Open Letter on the phylloxera issued by the Ministerio de Fomento, Dirección Gral. de Instrucción Pública, Agricultura e Industria, entitled "Nota sobre la Filoxera de la vid a los viticultores españoles". Published in Madrid, on the $1^{\text {st }}$ September 1878 .
} 011 Bentham Open 
international trade between England, that produced textile products, and Portugal, that produced wine [3].

More recently wine has still played (in fact, it still plays) a major role in some regional economies ${ }^{3}$, this time spread all over the world, as viticulture has expanded in the last centuries from its traditional producing area to the Americas, southern Africa and Oceania. The socioeconomic role of wine in some regions has been a major issue for national and supranational institutions, and for the regions with large wine producing sectors $[4,5]$. The development of economic clusters around the wine sector has been studied in a number of approaches: some authors have measured the economic impact of wine in the producing regions [6, 7], and others have conducted economic analysis of the wine sector itself [8].

Another approach for showing the current social relevance of vineyards and wine-making industries may be found at the international level, in the World Heritage list. UNESCO, the United Nations Educational, Scientific and Cultural Organization, seeks to encourage the identification, protection and preservation of cultural and natural heritage around the world, when considered to be of outstanding value to Humanity. Hence, at the end of 2009 there are 890 sites around the world forming part of the cultural and natural heritage of Humanity, that belong to all the peoples of the world according to the international conventions on World Heritage. It is important to note that there are six wine regions ${ }^{4}$ included in this list because of their vineyards, and at least four other sites ${ }^{5}$ in which vineyards or wines have played a relevant role in their evolution, and as a consequence in their selection for the world heritage; thus, those vineyards are considered as having outstanding universal value. Related to this, a real proliferation of wine tourism has occurred in recent times, as more sophisticated wine consumers are looking for a wine experience in which design, landscapes, local culture and history, and high standard facilities add a significant value [9].

In this paper, the Rioja region is the subject of the analysis $^{6}$. This region is deeply linked to the vine-growing and wine-growing sectors, which play a leading role in the regional economy. In fact, wine is simultaneously the main Riojan characteristic, and the engine of its economic development. The Rioja wine sector has experienced an economic boom since the early nineties, ended abruptly with the global economic crisis begun in 2007. Nevertheless, the recent evolution of the wine sector has enhanced regional development in terms of social welfare; it has evolved from

\footnotetext{
${ }^{3}$ Jacques Berthomeau, a French top official, said in 2001 that "we talk about wines, it is a civilization, a way of being". In the original, "Le vin on en parle, c'est une civilisation, une manière d'être".

4 Alto Douro (Portugal), Lavaux (Switzerland), Tokaj (Hungary), Pico Island (Portugal), Saint-Emilion (France), and Upper Middle Rhine valley (Germany).

The full Heritage list may be consulted at the following site: www.whc.unesco.org

5 Bordeaux (France), Fertö-Neusiedlersee (Austria), Costiera Amalfitana (Italy), and Portovenere (Italy).

${ }^{6}$ Rioja wine producing region includes vineyards in southern Alava (in the south of the Basque Country), south-western Navarre and northern La Rioja, thus not corresponding to a single political or administrative region.
}

being a rural and poor region in European standards (a middle level region in Spain) up to become for some years the Spanish richest region under some indicators, with a GDP per capita over European average. Even though the effects of the economic crisis begun in 2007 will be severe, the investments made in Rioja during the nineties and early years of the XXI century, and its positioning in the global wine market will give this region a solid ground for further development.

This paper is organised as follows: after this introduction on the diverses roles of wine, section 2 summarises the main contributions to wine producing regions analysis, discussing some of the problems arisen when using the cluster concept in areas like Rioja. Section 3 presents the historical roots of the wine industry in Rioja, showing that it has played a leading role in the socioeconomic evolution of the region. Section 4 comments the structure of the Rioja wine cluster, and presents a valuation of its relevance in terms of GDP. Section 5 sheds additional light in the relation between Rioja wine and its territory, using the industrial district framework. Section 6 briefly proposes an enlarged theoretical framework, tailored-made for Rioja, the Oenopolis. Finally, the last section summarises the paper.

\section{THEORETICAL REVIEW: RESEARCH ON WINE REGIONS}

The wine sector has been studied in a scientific way following different approaches since the XVIII century: we can cite topographic atlas of the distribution of wine varieties, and producing regions as the book by André Jullien in 1816; or economic analysis like the report on the wine sector written by Felix $\mathrm{M}^{\mathrm{a}}$ de Samaniego in 1771. Oenological literature has a milestone in Louis Pasteur's work in wines, published in 1866.

The modern economic analyses of wine producing regions mainly use one of two close concepts, the industrial district or the cluster. Both emphazise the importance of the geographical concentration of interlinked economic activities, improving studies using the traditional sectoral surveys. In our understanding, which differs from that of Zanni et al. [8], a combination of both approaches would be more appropiate than privileging the latter; as the industrial district conceptual framework would provide a helpful insight, usually missed in the cluster analysis.

According to Porter [10], a cluster is "a geographically proximate group of interconnected companies and associated institutions in a particular field linked by commonalities and complementarities". Porter shows that the cluster approach is better than the traditional "sectorial analysis" to determine the competitive advantages of a certain territory or industry.

Cluster analysis fits the wine industry perfectly; in fact, Professor Porter, the leading academic in the field, has used the California Wine Cluster as an example of the creation and development of clusters $[11,12]$ and Harvard University employs a case study on this Cluster to encourage discussion on the concept. The success of this approach can be seen in the studies on the California Wine Cluster [13-18]. Wine clusters have also been studied in other world regions: Aquitaine in France, Victoria in Australia [19], Cape Town in South Africa [20], Chile [21], New Zealand [22], Canada 
[23, 24], Canary Islands in Spain [25], Italy [8, 26], Mendoza in Argentina, Rioja itself [9], etc.

Despite the suitability of the Porter framework, and more generally of clusters analysis, to wine producing regions, some criticisms may be made on the previous literature about wine clusters. First of all, most of the researches do not attempt to measure the cluster's economic impact, thus avoiding decisive information about the cluster regional significance. Furthermore, among those devoting some space to economic impact, the overall contribution to regional GDP is seldom considered. Instead of it, more accesible data as the aggregation of the total invoicing of all the industries within the cluster is generally used as a proxy of the cluster's contribution to the regional production [24, 25], hence posing a "double counting" problem. A more accurate way of determining the "economic impact" of a given cluster, consisting in the use of Input-Output (IO) tables [27] has seldom been used in the wine producing regions; Larreina and Aguado [9] use this analysis to determine the regional economic impact of wine.

An additional problem of the academic literature is that wine clusters have been mainly studied in the new producing countries; that is, even at Bordeaux, where some 55,000 people are supposed to be working in the "filière vitivinicole" there has been scarce research on the socioeconomic dynamics of the wine cluster. Hence, some features of these new producing countries have shadowed the peculiarities of more traditional wine producing regions, so that using the same approach misses significant information. For instance, in many cases wine clusters do not have a significant regional impact, as they refer to national level or to very large states $[20,28]$, where the regional impact of wine is diluted. In fact, if we compare the California and the Rioja wine clusters, we find that while $18 \%$ of the land is under vines in Rioja, only $0.5 \%$ of Californian soil is used to cultivate vineyards. Moreover, wine cluster workers are only $0.2 \%$ of the total population in California, while they exceed $4.5 \%$ in Rioja. The different local impact of these two clusters is evident.

Sometimes, we may find even difficulties to consider the wine industry as an effectively ongoing cluster, lacking common institutions, synergies or even the spatial proximity. In the case of Chile, wineries are spread over a narrow band of land 1,400 km long, to account for a wine sales volume $30 \%$ higher than that of Riojan wineries that are located not further than $50 \mathrm{~km}$ away from Logroño. The Chilean regions producing wine are heterogeneous in vinification techniques, commercialisation strategies, etc; meanwhile Rioja wine producers must follow a common set of strict rules involving yields, varieties, vinification technologies... Furthermore, until quite recently Chilean wineries were too individualistic and with no relevant synergies [21,29].

Some of these weaknesses may be addressed by using the "industrial district" concept in adition to the cluster analysis. In its modern version ${ }^{7}$ an "industrial district" is defined as " $a$

\footnotetext{
${ }^{7}$ Modern researchs about industrial districts are based on Marshall works from the late XIX century, included in Principles of Economics: an introductory volume [32]. In his own words, for the inhabitants of the district "the mysteries of the trade [of this specific product] became no
}

socio-territorial entity which is characterised by the active presence of both a community of people and a population of small and medium size firms in one naturally and historically bounded area. In the district, unlike in other environments, such as the manufacturing towns, community and firms tend to merge" [30]. This concept has been developed since the late seventies by the Italian professor G. Becattini and other Italian academics, in reference to certain Italian cities, mainly in Tuscany and Emilia-Romagna, which happen to have the classical marshallian "industrial atmosphere". Becattini has also proposed the concept of "agro-industrial district", reflecting the singularities of the agroindustry [31]. The "industrial district" literature stresses some social causes of the economic performance such as local history and culture, shared social beliefs and feelings, etc. At the same time, industrial districts rely on a specific sort of firms: small and medium size enterprises, while clusters can be formed around a single gigantic company. Hence, cluster analysis may be improved by including these features related to traditional wine producing regions and that have had a role in their development, like history, soil caracteristics or local culture, as it is the case for Rioja, as we will show in the following sections.

\section{WINE IN RIOJA: BUILDING A CLUSTER THROUGH A MILLENIUM}

Rioja wine region is located in the North of Spain, in both margins of the mid Ebro valley; it has 310,000 inhabitants and its prestigious vineyards spread over 64,000 hectares. Among the natural advantages of this area for wine production we can cite a mild and dry climate; a mountainous range running from West to East protecting most of the territory from the wet and cold North-west winds; a clear exposition to the south in a large fraction of the territory, placed in the slopes of those mountains, a poor soil, that prevents large yields and favours wine quality... [36].

Rioja wine region does not correspond to La Rioja Autonomous Community, a situation that may be slightly confusing. Half of La Rioja territory does not belong to Rioja wine region and, at the same time, around one third of Riojan vineyards belong to the Basque Country and to Navarre, as many of the most prestigious wineries do. In Fig. (1), the location of Rioja vineyards in Northern Spain is shown. Municipalities with a large vineyard (over 500 has.) are shown in dark green, whereas Riojan municipalities with lower surfaces under vines are shown in light green. Finally, other municipalities of La Rioja, Navarre and the Basque Country that do not belong to Rioja are shown in yellow, and areas belonging to other regions in white. The distance between Alfaro, the dark green municipality in the SouthEast end of Rioja (right of the figure), and Labastida, the

mysteries; but are as if they were in the air, and children may learn many of them unconsciously", Marshall [32, pg. 271]. Marshall also wrote that "when an industry has thus chosen a locality for itself, it is likely to stay there long: so great are the advantages which people following the same skilled trade get from near neighbourhood to one another. [...] a localized industry gains a great advantage from the fact that it offers a constant market for skill" [32, pg. 271], thus preceding the spatial application of QWERTY economics [33-35]. 


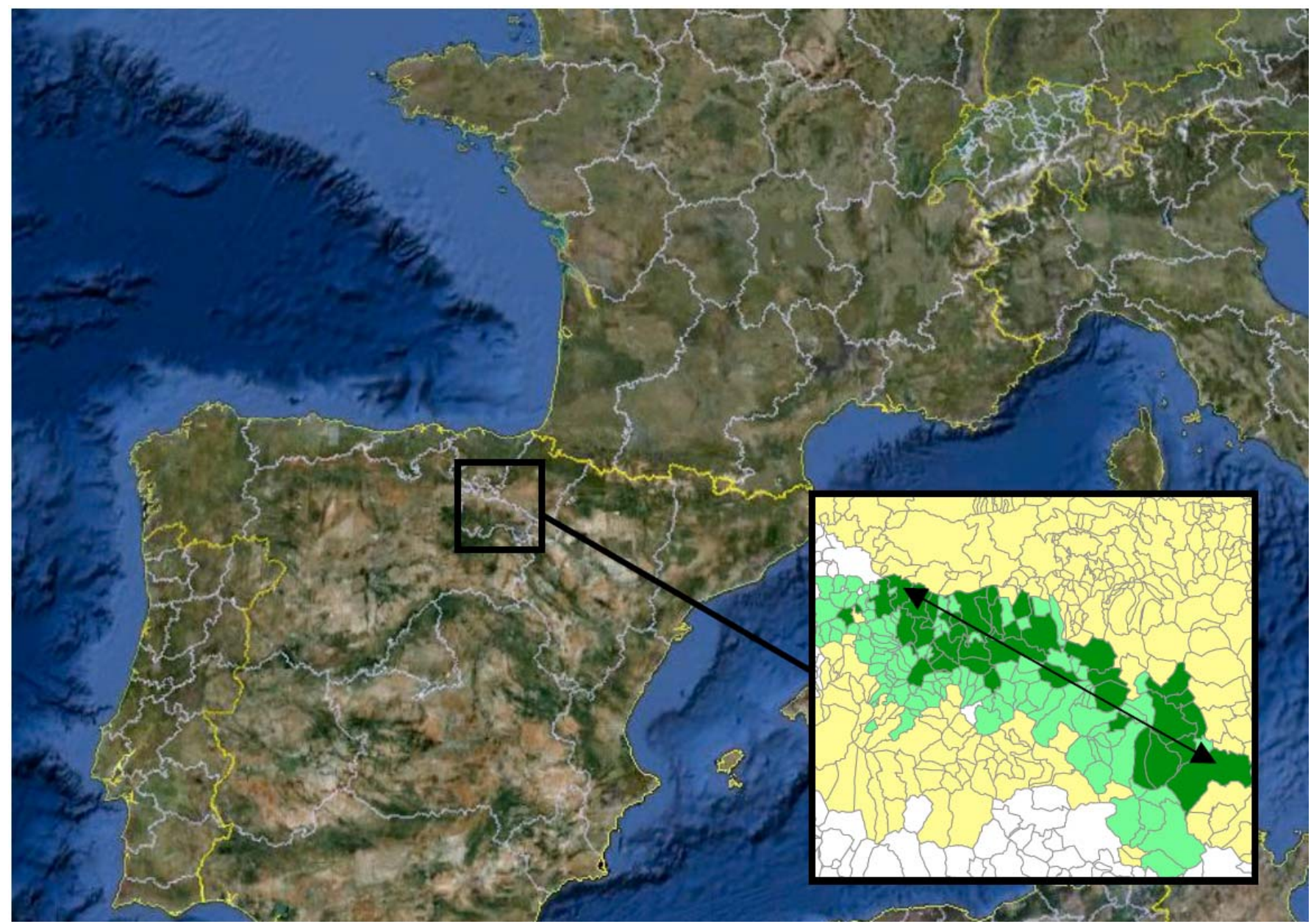

Fig. (1). Rioja location in Northern Spain.

dark green municipality in the North-West end of Rioja (left and up) is around $100 \mathrm{kms}$ and is shown with the arrow.

This current situation, in which the wine producing region of Rioja is split into three different Autonomous Communities, has not always ocurred. In fact, during a long period of the Middle Ages there was no administrative or political separation, as all this territory belonged to the Kingdom of Navarre; this was the time in which the seeds of the current Riojan cluster started to be spread. Obviously, some favourable climatic, edaphic and botanic features are relevant for the wine industry, but the human factor is a crutial element for the success of this sector.

The interaction between men and Riojan soil around wine can be traced back uninterruptedly to the Early Middle Ages. At that time, and once a long period of wars and depopulation was over, people coming from northern Navarre settled in the Riojan area, reintroducing the vineyards first brought to the region during the Roman Empire $^{8}$. In the existing documents dating from the IX and $\mathrm{X}$ centuries there are references to small vineyards in the region. The positive evolution of this crop is shown in the XI century, when vineyards located in the present Rioja are

\footnotetext{
${ }^{8}$ A well documented history of Riojan wine may be found in [36, 37]. These works also address in depth the determinants of the boom in Rioja wine occurred since the early nineties.
}

usually a relevant component of inheritances and donations to the large Monasteries of the Kingdom of Navarre made by nobles and wealthy individuals living in the area. At the end of this century, the southern part of Rioja was conquered by the neighbouring kingdom of Castille; aside from some punctual periods of Navarrese dominion in the following centuries, the political separation between different areas of Rioja has continued since then.

In the XIII century, there was already a large wine business in the northern side of the Ebro River (currently, Rioja Alavesa and La Sonsierra). Local councils in the Castillian Rioja claimed to their Sovereign that the villages belonging to Navarre were wealthier and more populated due to the decission taken by the city of Vitoria to be provided exclusively with wine coming from the Kindgom of Navarre. The fact is that Navarrese documentation of that time shows that the people living in what was called at the time "Sonsierra navarra" made their livings by producing bread and wine". Even after Navarre was conquered definitely in various steps during the XV and XVI centuries, this local specialization in the wine industry remained. In the

\footnotetext{
${ }^{9}$ In the XIII century, the first known poet writing in Spanish, Gonzalo de Berceo, who happened to be of Riojan origin and lived in the region, lauded "a glass of good wine" (un vaso de bon vino), what he considered an appropriate pay for his verses.
} 
following period, specialisation in the wine business increased; thus, in the XVI and XVII centuries, several villages in the area were said to have a wine monocultive.

This overdependence in the wine sector led to several crises that struck violently the region: in the first place, a cooling period in the late XVI century harmed several consecutive harvests, and many villages were not able to produce wine enough to buy the goods they needed to adequately feed themselves. When a disease was spread through these weakened inhabitants, it wiped out two thirds of the population in some villages, and halved the total population of the area.

Decades after, already in the XVII century, a surge in the demand of coastal villages (Bilbao, Bermeo, etc.) stimulated wine production in Rioja, and expanded vineyards up to become the only agricultural product in some villages of the region. This specialization in wine production was brought to the extreme and an overproduction crisis happenened in the mid XVIII century. For instance, there is a report dated in 1771, made by the writer of fables Félix de Samaniego, resident in the Rioja Alavesa, and sent to the Sociedad Bascongada de Amigos del País, the Basque economic and scientific society created during the Enlightenment. In this report, the writer claims that "the excessive area devoted to vineyards is provoking the strongest consequences; and, to my understanding, it is the root of all the other ills that are consuming the territory of Laguardia". ${ }^{10}$ The ills to which he is referring are that "once the country has been reduced to the only cultivation of wine, and being in trouble its commercialization due to its abundance, the cheapness follows" $" 11$ engendering sufferance and poverty in all landowners, peasants, wine-makers and related professions.

Alarmed by the difficult situation that this sector was going through, and the consequent decay and ruin suffered by the Riojan economy, the Basque Society organized a contest in 1785 , awarding a prize to whoever proposed the best way to "make this region happy [...], specifically in what is related to selling its very large wine production" ${ }^{\text {. }}$.

Several papers were presented to the Society, and some of them, including the anonymous one that obtained the prize, proposed to leave the traditional method of elaboration, that should be substituted by the method of Bordeaux wines, at the time much better in terms of quality and capability to be shipped to far away destinations. At the time, the Americas could have been a large and profitable market for Riojan wines, but inappropriate oenological practices made long travels impossible, as the wine lost all its qualities during the transportation. In 1787, Manuel Quintano, a priest living in Labastida who have visited Bordeaux the previous year in order to learn about their

\footnotetext{
${ }^{10}$ This is an approximate translation from the Spanish. The original reads like this: "La excesiva extensión que se ha dado al cultivo del viñedo está produciendo la mas fuertes consecuencias; y es, a mi entender, la raíz de todos los otros males que consumen a este tercio de Laguardia”.

${ }^{11}$ As previously, this is an approximate translation from the Spanish. The original reads like this: "Reducido el país a solo el producto del vino, y dificultándose la salida de este género por su abundancia (lo que experimenta ya) se sigue la baratura".

${ }^{12}$ The original reads like this: "hacer feliz esta comarca [...] a dar salida a su abundantísima cosecha de vinos".
}

wine-producing technology, prepared the first Riojan wines elaborated with the method of Bordeaux, that were said to be "the most delicious [wines] made to date in Rioja". Furthermore, these wines were able to travel to the Americas keeping their quality standards, hence enlarging the potential market for Rioja wines until then limited to surrounding areas, mainly in the Basque Atlantic coast.

The previous story is probably the first technological transfer to the Rioja wine sector since the Romans, and the first documented Riojan wine produced in a modern way. If we analyze this transfer of a leading technology in the light of modern concepts, we would say that it was motivated by a preliminary local SWOT analysis of the sector, in which a sound determination of the main problems and their roots was made: after a demand-driven surge in the sector, overcapacity had engendered widespread misery, and new markets had to be found. Then, a regional government in charge of local socioeconomic development decided to support research and development within the industry. Afterwards, some private entrepreneurs conducted an international benchmarking analysis, in order to find the global best practices of the time, which allowed them to ship their wines to far markets without diminishing their quality. When they did identified these best practices, then they got some Governmental help for fostering this innovation, even though it highly depended on private funding... and here we will find the largest obstacle for a change in the sector during the XVIII century.

Even though other Riojan winegrowers elaborated small quantities of wine following the Bordeaux method in the 1790 s, this early attempt to modernize wine production in Rioja was a failure. First, this method demanded a large supplementary investment when compared to the traditional way of producing wines in Rioja (in a non exhaustive list: fruit should be selected; oak casks should be bought; wine should be kept stocked during a long period for aging; etc.). Second, there was a long period of political instability and wars that impoverished the region, and made it impossible to conduct the needed technological evolution.

Meanwhile, in the southern part of the Rioja region, another enlightened society was founded, the Real Sociedad de Cosecheros de la Rioja Castellana, with strong links to the wine sector (as "cosechero" is the traditional name for winemakers in the region). This society focused on developing and maintaining roads, critical for reaching in appropriate time and cost the consumers of Rioja wine.

Despite the failure in modernizing the sector immediately, the movement begun in the 1770 s sprouted in the first two tiers of the XIX century ${ }^{13}$, particularly in the 1860s. In fact, in 1860 the regional government of Alava hired a highly reputed French oenologist coming from the Bordeaux region, Mr. Jean Pineau, in order to teach Riojan wine-growers how to improve the quality of their wines. The result was quite satisfactory; as a wine called "Medoc

\footnotetext{
${ }^{13}$ In this period a number of books, works and papers were using the same arguments about the poverty of the region, the capability to create wealth by producing better wines, and the use of Bordeaux wineries as a reference. Even when there was no visible sign of a renewal in the oenological procedures, there was a growing acceptance of its inevitability.
} 
alavés" (Médoc-style wine from Alava) was given a prize in the international exposition of 1864, held at Bayonne.

Once again, the large investments demanded for the transition to the new technology made most of the winegrowers step back, but the success encouraged a noble man who was wealthy enough to conduct this project and establish the first modern winery in Rioja. This man, Camilo Hurtado de Amezaga, Marqués de Riscal, had lived in Bordeaux so was familiar with the industry, and simultaneously had inherited vineyards and a winery in Elciego, in the heart of Rioja. In fact, he had obtained as well a prize in the exposition of Dublin in 1866. When the contract of Mr. Pineau with the Alava government expired in 1868, Camilo Hurtado de Amezaga hired him in order to build a large and modern winery in Elciego. His wines obtained further successes in the expositions of Wien (1873) and Bordeaux (1895). Simultaneously to the foundation of the winery "Marqués de Riscal", another Marquis, Luciano de Murrieta, established a modern winery near Logroño, fully operative in 1872, and a reputed wine producer in Rioja ever since.

This time the modernization of Rioja wine did really happen. The seeds spread in the XVIII century led to the blossom of modern wineries in the last quarter of the XIX century. Several factors were determinant for the success of wine capitalism in Rioja at that time. First, the industrialization of Biscay, which experienced a great population growth linked to the economic boom, enlarged the traditional market of Riojan wines. In fact, the region around Bilbao doubled its population in the second half of the XIX century, increasing accordingly the consumption of wine from Rioja. Second, new infrastructures were laid simultaneously; for instance, the railway from Bilbao to the Ebro valley, inaugurated in 1863 reduced significantly transportation costs and made Rioja and Bilbao much closer. The same was true for the French border and the seaport of Pasajes, as the Madrid-Irún railway ${ }^{14}$ was fully operative in 1864; this was extremely important when the insect phylloxera attacked French vineyards in the 1870s, the third factor to be considered. This microscopic louse, a pest of vineyards native to North America, quickly destroyed most of the European vineyards when inadvertently brought to Europe, hence creating for some years a large market in France that Rioja was able to serve thanks to the new railways, what attracted French winemakers to invest in Rioja. Finally, a fourth factor was the creation of wealth linked to the industrialization; this allowed the wine sector in Rioja to raise the fresh capital needed to develop the industry. In this sense, it is telling to know that capitalists from Bilbao invested in the Riojan wine sector while not investing simultaneously in other wine regions placed at a similar distance. Furthermore, few industries outside Bilbao received any investment at the time.

The coexistence of these factors led to the establishment of new wineries in the Riojan wine sector; at the same time, the availability of Basque and French capital made most of

\footnotetext{
14 The Madrid-Irún railway was connected to the Bilbao-Tudela railway at Miranda de Ebro, a town near Vitoria that is mid-way between central Rioja and Bilbao.
}

them to be joint-stock companies. Bodegas Arízaga, López de Heredia, CVNE, Ugalde y Muerza, Bilbaínas, Paternina, Charles Serres, Martínez-Bujanda, Franco-españolas, and many other still functioning wineries were founded before 1900. Hence, in the beginning of the XX century we can find modern wineries, designed and managed in a scientific way (in all agronomical, oenological, and managerial senses), that acquired a growing share of the wine production in Rioja, even though they were still a small fraction of the production.

The XX century was a hard time for the wine sector in Rioja until the 70s. To begin with, in 1900 the phylloxera appeared in the region, and in a few years destroyed almost all Riojan vineyards. The loss of income endured by vinegrowers, and the huge investments needed for reconstructing the vineyard, forced many small peasant and vineyard owners to sell their properties and emigrate towards large industrial areas outside the region. On the positive side of the first part of the XX century, we can point to the creation of the Denominación de Origen Rioja in 1926, after several unsuccessful attempts to protect the Rioja wine; unfortunately, the operations conducted by the Consejo Regulador ${ }^{15}$ were initially scarce and it took several decades to settle an effectively operative Denominación de Origen.

Later, the global economic crisis of the thirties and the consequences of the Spanish War, including commercial isolation, were severe downturns for the economy of the region. The situation remained complicated for the Riojan wineries and vine-growers, as the Spanish domestic market of the late forties and early fifties was very weak, and the foreign markets were barred for a long period in an unsuccessful attempt to bring down the dictatorship.

In the seventies, the Spanish economy was growing at a fast pace and the future looked much more promising, with democratization and joining the European Communities clearly identified as two social objectives that could be reached in the following years. Even though viticulture was still ruinous for many vineyard owners, the installation at Rioja of Domecq wines, a successful winery from JerezSherry, was a turning point for the sector that slowly started a second modernization process.

In the eighties, several main changes transformed the Rioja wine sector. On one hand, demand for quality wines was becoming bigger as the domestic market grew and the low value of the peseta made Spanish products more attractive in the foreign markets. On the other hand, there was a collective decision towards competing in the wine market by offering higher quality, and the controls became stricter; this was recognized by the Spanish Government in 1991, when the Denominación de Origen became Calificada (DOCa Rioja), or qualified, the first of this kind among wine regions ${ }^{16}$. New wineries were built, some of them following

\footnotetext{
${ }^{15}$ The Consejo Regulador is the controlling body of the Denominación de Origen. Among its objectives, we can highlight that it applies the rules of the Rioja wine region, and ensures the compliance with Riojan standards. Furthermore, it encourages and monitors the quality of the wines labeled "Rioja", it promotes their image at the global marketplace, and, it defends the socio-economic interests of the sector.

${ }^{16}$ Rioja was the only wine Denominación de Origen Calificada until 2000.
} 
the "chateau" concept, and others larger in scale. Furthermore, a better educated generation took over the family wine businesses, and worked hard on them. These winegrowers could reinvest their profits, something unseen for decades, as their parents had not been able to make profits due to market conditions. These reinvestments modernized small and medium wineries and helped them to compete in quality with other wine producing regions. The domestic and foreign demand responded positively to these changes, and the wine sector in Rioja entered into a virtuous cycle.

Four consecutive devaluations of the Spanish peseta in the early 90s pushed the Rioja wine to a position of low prices and high quality; this led to a quick increase in foreign demand for Rioja wine. The period 1994-2005 was very successful for the wine sector in Rioja, especially in the late nineties: grape prices were skyrocketing, and final prices of wine were at historical maximums. Thus, in spite of fierce global competition, Rioja increased its surface under vines, the number of wineries, the sales of wine, and its value, attracting fresh capital and reinvesting a large fraction of the profits that were obtained. The changes experienced by the Rioja wine cluster were dramatic: productive vineyards passed from 42,000 hectares in the early 1990 s to just under 60,000 hectares in 2005 and around 61,000 hectares in 2008; grape production progressed from 210-220 million kilograms to more than 400 million, with a peak in 2004 of 470 million; the sales of Riojan wineries increased from around 200 million euros in the early nineties (using the conversion rate peseta-euro adopted in 1998) to more than one milliard euros in 2001 and thereafter, as can be seen in Fig. (2). The evolution of Rioja was opposite to that of the global market: these increases occurred simultaneously to global stagnation in the surface under vines, kept around 7.7-7.8 million hectares since 1993; to wine production ranging between 250 and 280 million hectoliters since 1993 (both variables well below 1980s values); and to a permanent imbalance, with supply being $10 \%$ to $20 \%$ larger than demand in the global wine market [38].

Other changes that took place in the region during this "great leap" of Rioja wine include a concentration in Tempranillo variety and ageing wines; large investments made in vineyards and wineries in order to modernize and mechanize operations; a deeper "socialization" of wine property as the number of vineyard owners grew from 12,000 in the eighties to an impressive 20,000 in $2004 \ldots{ }^{17}$. This improvement of the cluster was strengthened when a decisive step towards the integration of companies, institutions and individuals with interests in the sector (in a broad sense) occurred in 2004: the creation of the Interprofessional Organization of Rioja wine. This organization has close links to the Consejo Regulador of the Denominación de Origen Calificada Rioja, and promotes a common strategy and market positioning of Rioja wines.

\footnotetext{
${ }^{17}$ Note that the entire population of the region is slightly over 300,000 inhabitants. In the 2009 harvest there were more than 18,500 registered vineyard owners; the economic crisis, and low grape prices in the 20072009 period may have incentived landowners with small surfaces to sell their properties.
}

According to the yearly Nielsen report on wine consumption in Spain, Rioja is by far the leading wine region in the Spanish market. The sales of Rioja wines in the period 1999-2009 have been, as average, 39.2\% of the total sales of wines with Denominación de Origen in Spain. Simultaneously, Riojan surface under vines is only $10 \%$ of the total surface of Spanish vineyards protected by a Denominación de Origen. This maintained dominance of the market shows Riojan brand equity, much higher than those of its competitors ${ }^{18}$.

To conclude with this historical section, the consequences of the global economic downturn of 20082010 have been severe for a luxury product like high quality wine, which has suffered large reductions in sales. In Rioja, the volume of wine sold in 2009 was $14 \%$ below the maximum reached in 2007, when 272 million liters were commercialized; the loss in terms of value has been even larger. Whether this will be a temporary episode or a longer term trend is still very soon to tell; fortunately, and despite some errors made recently by economic agents in Rioja, we think that the wine cluster has strong fundamentals that will permit it to be in a strengthened position when the crisis ends.

\section{THE RIOJA WINE CLUSTER IN THE EARLY XXI CENTURY}

The Rioja Wine Cluster consists of several thousand of interdependent enterprises, including cellars and vine growers, in addition to suppliers and related companies, as shown in Fig. (3). The needs of Rioja wine industry are outstanding: more than 360 million bottles, labels, corks, etc. in the year 2006; most of them locally supplied. Total expenses of wineries in all operational expenditure (goods and services) and investments, account for $50.08 \%$ of wineries' production; almost $77 \%$ of these expenses are purchases from regional suppliers, so that $38.53 \%$ of wineries production corresponds to local purchases [7].

Furthermore, the level of investments has been quite impressive, as in recent times dozens of new wineries have been built in Rioja. The impressive dynamism shown by this sector has fuelled the machinery-making industry, the engineering companies and the regional architects among other sectors.

Thus, in Rioja, many enterprises of different sectors are dependent in the wine industry. In Fig. (3) the local sectors around the wine producing industry are identified, showing their links with the wineries, with the vine-growers or with both. In the mapping of the cluster, other sectors related to wine but not having a commercial relationship with it have also been included. As it is shown in the figure, there are non-Riojan wineries linked to the Riojan wineries. This is a mostly recent market-oriented movement of Riojan wineries, willing to expand their product portfolio; they have created or acquired common wine wineries that sell wines from outside Rioja. Others have chosen to invest in wineries under a variety of Spanish Denominaciones in other regions. Thus,

\footnotetext{
${ }^{18}$ During the same period, the second place in market share has been occupied by three different DOs (Valdepeñas, Navarra and Ribera del Duero). Altogether, these three DOs have an accumulated market share of 21,4\% (average 1999-2009).
} 


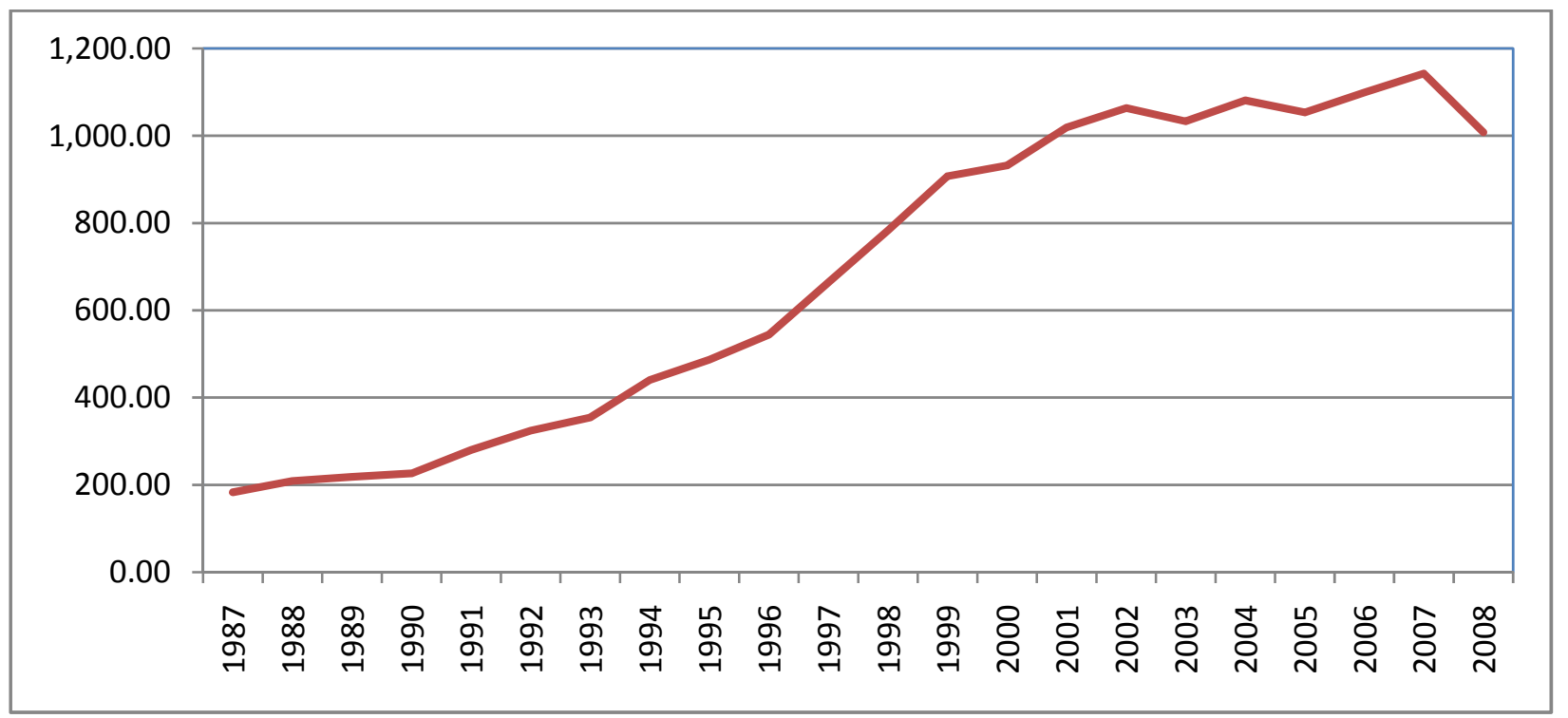

Fig. (2). Sales of Rioja wine in $€$ millions. Own research.

they have been able to complete their offer to large clients with a wider choice. There is as well a small production of Cava sparkling wines in Rioja, which is conducted by a few local wineries that have at the same time both Denominaciones: Rioja, for $90 \%-95 \%$ of their production, and a small production of sparkling wine under the Denominación de Origen Cava.

The economic impact of the cluster was calculated in [7] by gathering economic and financial data of the main companies of the cluster, in order to measure its share of regional employment and GDP; a sample of 108 wineries, accounting for a $90 \%$ of Riojan wine sales, and around fifty local supplying companies was used. In 2004 the Rioja Wine Cluster employed more than 14,000 direct workers, and the total value added by the cluster reached the amount of 1,250 million euros. That was the $21 \%$ of the GDP produced in the territories under the "Denominación de Origen Calificada Rioja".

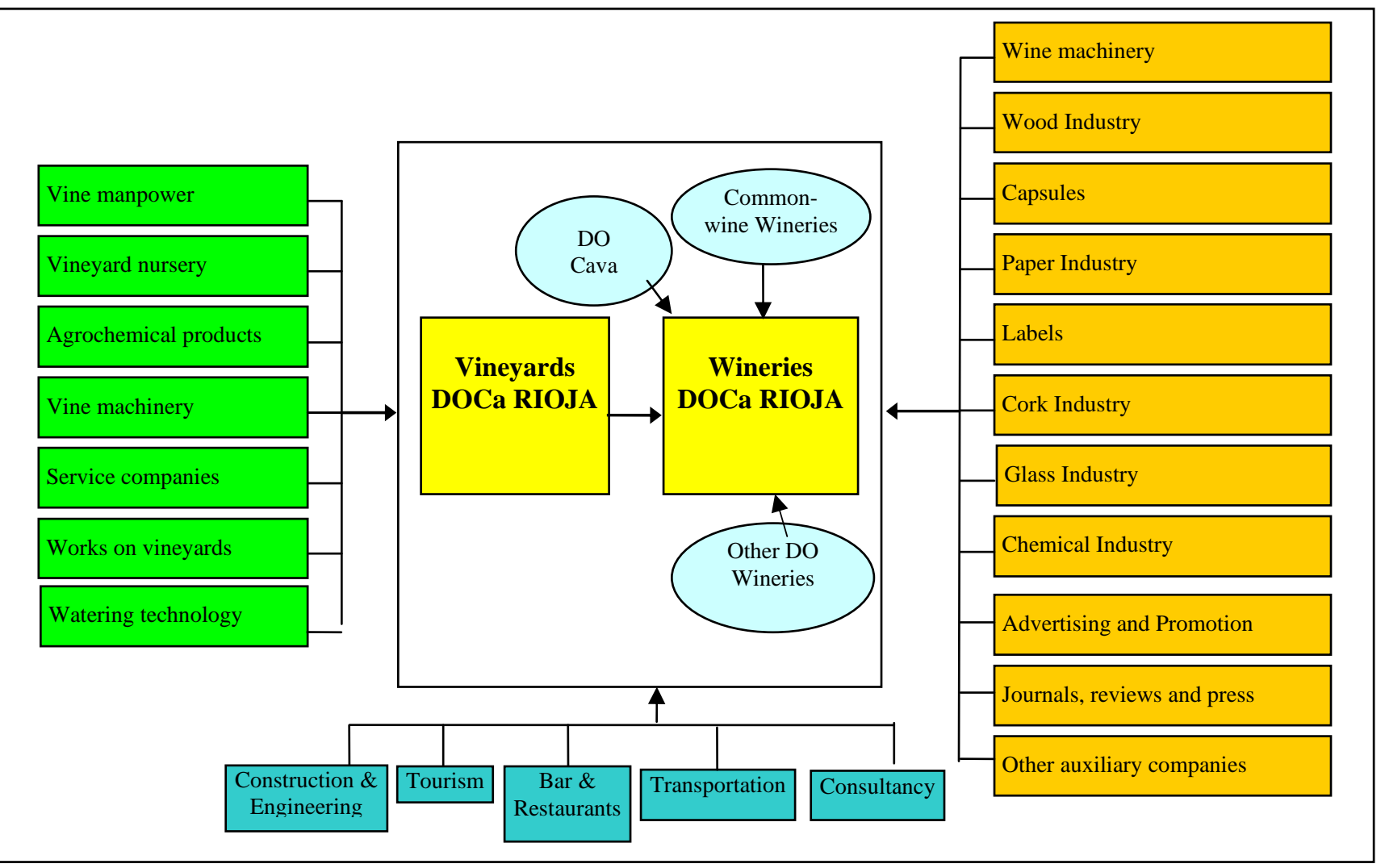

Fig. (3). The Rioja wine cluster. Own research. 
The wine cluster is by far the main economic activity in the Rioja region and, consequently, its evolution defines the region's wealth. In fact, the outstanding growth of the Rioja Wine Cluster occurred since the early nineties (the value added by Riojan wineries has multiplied by more than seven times from 1990 to 2005, being this last year half of their total turnover) is the main reason for the recent socioeconomic development of the Rioja region.

Furthermore, the impact of wine on Riojan households exceeds the large direct employment in wineries, vineyards and related companies, in 2005 twenty thousand additional people obtained some kind of income out of the Wine Cluster, as vineyard owners, wineries' shareholders, and suppliers' shareholders, among others [39].

\section{THE AGROINDUSTRIAL DISTRICT APPROACH. BEYOND THE RIOJA WINE CLUSTER}

As we discussed cluster \& industrial district approaches in section 2, the latter may add value to the former by including a mix of features that usually lay in oblivion. Most researchs on wine clusters in the New Producing countries ${ }^{19}$ do not pay large attention to the territory itself, beyond the need to be gifted with some natural endowments. Vineyards must be obviously placed in a well-defined area in which climatic and edaphologic conditions are adequate; but this is not the case for wineries or other related companies or institutions. In their logic, transportation costs of grapes from the vineyards to the productive facilities or of bottled wine from them to the main markets would determine the location of the wineries, as it may happen in other agribusinesses; only possible marketing reasons could favour building the winery within the limits of the vineyards, as "château" style wineries may attract more visitors, and therefore push forward sales. As the concept of Apellation d'Origin has been challenged in some new producing countries, we could understand the oblivion of terroir-related characteristics in a large part of the literature as a scientific by-product of a shared vision of the wine market in those countries, in which elements like history, shared rules and self-imposed constraints, external economies or a tissue of SMEs are not seen as competitive advantages for the future. Hence, the interaction between the wine sector and the social fabric is somehow neglected in those analyses.

In our opinion, the socieconomic component of the wine business at Rioja is one of its main strengths, so it should deserve a more structured analysis. This is why the approach of Becattini may be useful, as we have pointed out in section 2. Besides, despite the undeniable success of the cluster and the brilliant performance of many Riojan wineries ${ }^{20}$, most of

\footnotetext{
${ }^{19}$ Even though in some cases winegrowing started several centuries ago, all countries outside the traditional producing countries (Spain, France, Italy and others in the Mediterranean basin and around it) are grouped under the label "New Producing Countries" or "New World" (the Americas, South Africa, eastern Asia and Oceania). As a whole, NPC have gained market share at the expense of traditional producing countries during the last two decades: in the early eighties their exports were around $1,5 \%$ of the international wine market; in 2008 they were around 30\% [38].

${ }^{20}$ Some examples: Barón de Ley, which merited a whole chapter in Mora and Castaign [40] book on "bonnes pratiques dans le marketing du vin"; Juan Alcorta, cover photo for the book "Wine \& Design" [41] ; or Marqués
}

them remain region-based SMEs, and thus are neglected in large scale global analysis, as can be seen in Zanni [8]. In Fig. (4) we show our understanding of how the industrial district approach may add value to the wine cluster concept.

First, the close relationship between wine production and Rioja region is deep and longstanding, as we have shown in the third section of this paper: wine plays a leading role in the regional history. Simultaneously, regional culture and local society have both strong links with this sector; Rioja, as it is today, cannot be understood without the wine sector.

According to Becattini [30], the local accumulation of knowledge may be essential for a local system with the characteristics of an industrial district; in this sense, the fact that $20 \%$ of Spanish oenologists are based in Rioja region (while Rioja has a mere 6\% of the area under vines in Spain, and less than $1 \%$ of the country's population) is extremelly telling. Moreover, we must highlight the role of the regional Universities, in which wine-related studies are considered to be within the core field of study; and the existence of winespecific research centres located at Rioja, that produce and transfer wine-related knowledge to the different actors of the cluster.

The specificities of industrial districts enhance succesful new technologies and managerial approaches and facilitate quick transfers of knowledge from company to company. According to Nonaka [42], knowledge sharing is a necessary condition for producing new knowledge, so productive local systems as Rioja may have a positive impact in both the region's and the sector's competitiveness. In terms of how innovation is spread in Rioja, the use of architecture as a marketing tool for wineries could be an example. Following some regional early-movers as Bodegas Campillo in 1990 (although impressive buildings for wineries have been built in the region since the XIX century), first tier Riojan wineries focused on contracting global top architects (Gehry, Mazières, Calatrava, Hadid...) to work on their new facilities, a trend that was shared by smaller wineries on a more modest approach, contracting recognized local architects. This shows how a large number of companies within the sector may adopt a certain innovation. Beyond this, it has created a large synergy for the Riojan wine sector; the accumulation of individual companies' strategies of developing their facilities in order to attract visitors to their wineries and build a global image, enhance a common goal: making of Rioja a tourism destination (which it was not until quite recently). Precisely, promoting wine tourism is a declared objective for the three Autonomous Communities sharing the Rioja wine region, whose policies have encouraged private initiatives in this field. Wine tourism is considered to play a key role as a marketing differentiation tool for the individual companies and for the region itself; it has also been identified as a way of further developing economic activity in this rural area.

Another key feature of Industrial Districts is the sense of belonging to a local community, sharing a common system of values and rules. The Denominación de Origen Calificada imposes some rules protecting the public good represented

de Riscal, whose new building, hosting a Starwoods-Luxury collection hotel, is already an acclaimed masterpiece of Pritzker winner Frank Gehry. 


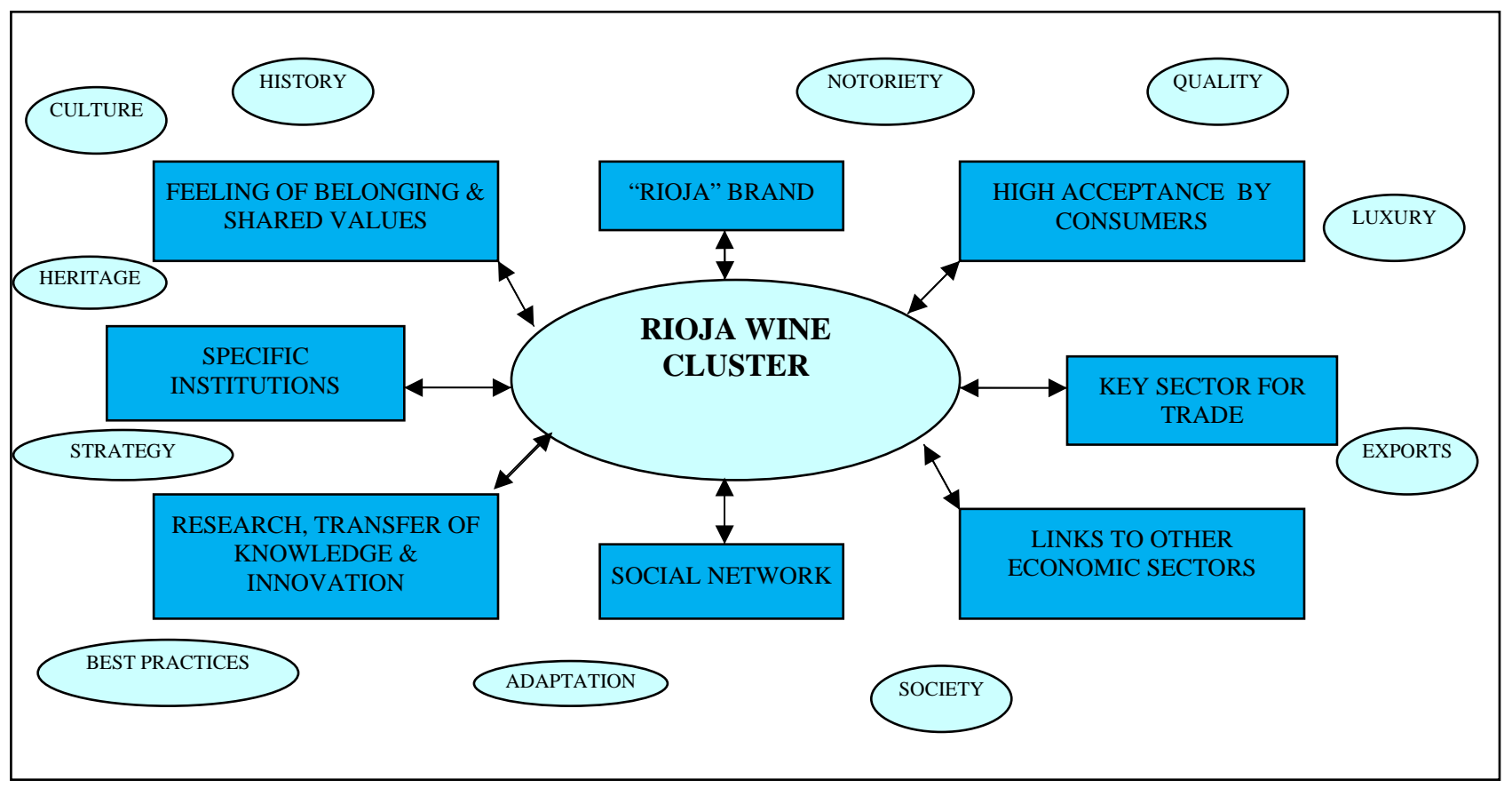

Fig. (4). The Rioja wine district. Own research.

by the "Rioja" brand, and prevents the action of free-riders. Besides that, the structure of specific institutions of the sector like the Denominación itself and the related Interprofessional Organization of Rioja wine, in which power is shared equally between the representatives of viticulturists and wineries, shows the willing to cooperate of the two main subsectors. These institutions reassure consumers of Rioja wine on the idea of buying "a specific way of elaborating wines", so that there are some common shared features among all Riojan producers ${ }^{21}$. Furthermore, just a single winery has left the Denominación and then has continued to operate in the wine market without this umbrella, while many others have been established in the Denominación, both new companies and already existing wineries operating previously in other regions. This is a clear acknowledgement of the importance that wineries give to the Rioja brand, and an acceptance of these self-imposed rules they share. We can find a reason for this in Castriota and Delmastro [43], as they show that minimun quality standards enforced by a controlling body (in Rioja case, the Consejo Regulador) has positive effects on collective reputation, and that this result holds when adopted voluntary additional quality standards (that would be the case, as Riojan regulation is very strict ${ }^{22}$ ).

${ }^{21}$ The role of these institutions and others is critical in many other senses as well. For instance, their market analyses remain powerful mechanisms to transfer knowledge about worldwide consumers of Rioja wine to all wineries in the region. These institutions are also in charge of the Strategic Planning for the Rioja wine sector.

22 As the DOCa Rioja is a qualified Denominación de Origen, the Consejo Regulador that controls the Denominación, compulsory performs analytical and organoleptic tests on all wines to be labeled "Rioja". Failure to show the sensorial characteristics (smell, taste, colour) adequate for Rioja wines results in the prohibition of the wine batch to be sold under Rioja label. The analyses are carried out in the official laboratories of the three Autonomous
A further example of this sense of belonging is the pride with which many wineries still produce their "maceración carbónica" wines, following ancient traditions in producing the wine (in fact, an updated version of the method previous to the Bordeaux-style production); even though these wines are a small fraction of total production, there are specific contests for them, and most small wineries keep producing them.

In Rioja another main characteristic of Becattini's Industrial Districts is present, the large population of internationally competitive SMEs. Whereas in some other wine clusters over the world there are only a few large companies that control the sector (Australia or even California being extreme cases), Riojan cluster consists of many small and medium sized family companies with limited market power, a typical characteristic of industrial districts. In Rioja there are more than 18,500 vineyard owners $^{23}$ (most of which are not linked to co-operatives), around 600 commercialising wineries (among which the twenty largest groups only commercialise less than two thirds of total Rioja wine sales) and some hundreds of suppliers and related companies. The recent dynamics of the cluster have fostered start-ups and new-comers from other regions, enlarging the number of independent wineries that commercialise their wines. Another feature of industrial districts is reciprocal trust, what we can identify in the long term relations between some wineries and many local

Communities, and the blind tastings are performed by a panel of grape growers and oenologists.

${ }^{23}$ Many of these vineyard owners have other main economic activities (as they work in the industry, the service sector, or are retired), so there is a high degree of pluriactivity, enhancing the relations between viticulture and many other sectors. 
viticulturists that supply them ${ }^{24}$. In this sense, it is usual that winegrowers have pluriannual contracts with ageing wineries; the latter help the former to keep high quality standards in their production (technical support and advices) and only accept high quality grapes or wine (controlled before the delivery). This favours the existence of independent winegrowers in Rioja, who may sell the grapes directly or ellaborate wines in microwineries before selling their production to wineries. In the case of winegrowers associated to co-operatives (40\%, accounting for $37 \%$ of Riojan harvest) there are large differences in their marketing approaches; only a small number of co-operatives focus on commercialising their wines in the Spanish or foreign markets, while the others sell most of their wines to other Riojan wineries shortly after the harvest.

This particular structure of the Rioja Wine District implies that in this region there is a sound social base backing up the wine sector. In fact, this social base is very broad, with an estimate of 34,000 people obtaining direct incomes from the Wine Cluster in 2006 (slightly less than one third of Riojan households). The distribution of the profits made by the Rioja wine sector during the period 1998-2005 has favoured all economic agents involved in the cluster, spreading out its wealth to the rest of the socioeconomic sectors of the region. After 2005, prices have been much more moderate, so the spillover effect of wine profits has been reduced. Another by-product of this widespread social base is that information flows through formal and informal social networks, beyond sector-specific institutions.

Apart from the specific socio-economic structure of the Rioja region, there are other features of Rioja Wine Cluster that correspond to those of an industrial district [30]. For instance, the production is aimed at the global high quality market, as the recent success of the Rioja wine may show. One third of Rioja wine production is exported and the importance of the foreign market is even bigger in top quality Rioja wines: exports of wines with the highest added value have reached a $45 \%$ of these wines' sales, on average, since the early nineties. At the same time, Rioja wine is by large the main product exported within the region; the annual money inflow of $300-350$ million euros is over $25 \%$ of the region's total exports ${ }^{25}$. It is relevant as well to highlight that in terms of value added, the Riojan wineries' GVA has been around $45 \%-50 \%$ of the turnover during the period 20002005 , more than double the figures of their counterparts in other Spanish regions, or those of other Riojan agribusinesses.

The economies of scale linked to the Rioja Wine District are a crutial tool for small and medium Riojan wineries in their competition with much larger wineries from other countries or regions. For instance, the Consejo Regulador's budget for 2010 includes 10 million euros to be spent in promoting the Rioja wines in the main foreign markets. This helps the commercialisation of small wineries' production in

\footnotetext{
24 The early XX century, when the after-phylloxera plantations took place, saw situations in which this reciprocal trust was strengthened, as some large wineries cooperated with other producers during the crisis, and helped local wine-growers to buy and take care of baby-vines.

${ }^{25}$ Within the Spanish wine exports, Rioja is the leading region in both volume and prices.
}

markets that in other circumstances would be beyond their reach $^{26}$.

Finally, Rioja is totally identified with its wine by both local and foreign people, as the first president of the Autonomous Community of La Rioja stated in 1985. In the first case, a survey conducted in 2004 stated that the inhabitants of Rioja associated their region to wine, considering wine as the main identifying character for their region [44]. We can also point to the recent tourism promotion of La Rioja Autonomous Community, which has used the slogan "the region with the name of a wine"; or even to the name itself of this Autonomous Community, created in the early $80 \mathrm{~s}$ when the previous province of Logroño became La Rioja. In the second case, other Spaniards and Europeans equate Rioja with quality wine [45], recognizing the brand "Rioja" and considering it trustworthy. It is the best-known Spanish wine region, and one of the most reputed wine regions in the world. But beyond this, Rioja wine has the highest brand awarenessinto-purchase ratio on international markets of any wine region in the world, including those like Bordeaux, Burgundy or Chianti [45]. This is highly relevant, as around $50 \%$ of consumers who recognize the Rioja brand also buy wines from the region.

\section{THE OENOPOLIS, A REGION DRIVEN BY WINE PRODUCTION}

As we have seen in the previous sections, the production of wine in Rioja has developed a succesful cluster, and its close links to the regional society make it an industrial district, according to Becattini's features. An additional step beyond is to consider that most economic developments in Rioja are connected to the evolution of the wine market. This is why we proposed the concept of Oenopolis, meaning that Rioja is a region in which main socieconomic changes are driven by the changes in the wine industry, which has fostered innovation and regional competitiveness. This concept would cover a wider set of variables and relations than the cluster or the industrial district, and is specifically referred to Rioja, where most of the agents linked to the wine sector are placed less than $50 \mathrm{kms}$ away from Logroño.

For instance, we can point to the relation between the region's unusual inflation ${ }^{27}$ during the nineties and early years of XXI century [46] and the evolution of wine-related income. According to Larreina and Gómez-Bezares [47], the contemporaneous increase in productivity in the wine sector has engendered a higher inflation in the region through an increase in agrarian rent, and not through an increase in wages (as the classical Balassa-Samuelson effect). The effect of the increase in Riojan household income was to fuel aggregate demand in goods and services at the regional level. The demand shock, within an economy enjoying full-

\footnotetext{
${ }^{26}$ The Consejo Regulador is mostly funded by fees paid by wineries and winegrowers of the Rioja region; it receives as well some minor subventions from the European Union and the regional governments.

${ }^{27}$ In fact, Hubrich (2008) has found that only between $50 \%$ and $75 \%$ of variations in inflation at Rioja in the period 1996-2004 are explained by euro area-wide factors. This result is much weaker than in all other Spanish regions, where at least $75 \%$ of the variance is explained by these European factors.
} 
employment, had two different consequences: upwards tensions in prices (especially for goods and services supplied in a regional basis ${ }^{28}$ ) and a certain "pull effect" in foreign immigrants, that entered the Riojan labour market in thousands. In this sense, in the period 1991-2006, while the wine sector multiplied by 5 the value of its production, the flow of immigrants was continuous. As late as 1996, the percentage of immigrants in Rioja was still below $0.8 \%$ (1.4\% in Spain), while in 2006 it was already $11.5 \%(9.2 \%$ in Spain $)^{29}$. Regarding general demography in the region, in a much longer period (1990 to 2004) there is a relation between the maintenance of the population in Riojan rural municipalities and their density of vineyards.

Another main change occurred in the Riojan society, and related to the performance of the wine sector, is the dramatic increase in the standard of living experienced in the region while the great leap of Rioja wine was happening. The "Encuesta Continua de Presupuestos Familiares" (Household Budget Continuous Survey) shows that Rioja in 1991 had $16.5 \%$ of households claiming to reach the end of the month "easiliy" or "very easily" in financial terms, slightly over Spanish figure of $14.4 \%$. In 2000-2004, the average percentage of Riojan households in this situation was $29.9 \%$, while the figure for Spain was just $16.2 \%$ [48]. Furthermore, in the same period 2000-2004, we find that Rioja was the Spanish region with a lower ratio of families suffering financial stress for reaching the end of the month [48]. As explained in Larreina and Aguado [7], the links between regional welfare and the successful performance of the wine sector lay in the large number of households in the region that have obtained incomes from the Rioja wine cluster enterprises during this period.

\section{CONCLUSION}

In this paper we have explained how a cluster has been developed around the Riojan wine industry, and the effects of its successful evolution in the last decades. Even though this paper highlights the decisive influence of the wine industry in Rioja, it is likely that a similar story could be told about other leading wine regions like Bordeaux or Champagne, in which the evolution of the wine market has been a major force driving their economy and society through History.

In section 2 we have reviewed the main literature on wine clusters and agro-industrial districts, stressing the complementary between both approaches. In section 3 we have reviewed the evolution of the wine producing sector since its first steps in Rioja, a millennium ago, showing its deep roots in the region and some key factors for the surge in demand it has experienced since the nineties. In section 4, we have presented the cluster of Rioja wine as it has been at

\footnotetext{
${ }^{28}$ Even real state properties were affected by this flow of capital to Rioja, engendering since the late nineties a construction bubble with some different roots from that that took place in other Spanish regions afterwards. The Vicepresident of La Rioja, Aranzazu Vallejo, made a explicit link in the regional Parliament in the year 2000 between the incomes of viticulturists and the price increases of Riojan homes (Minutes of Sessions in the Parlamento de La Rioja, $29^{\text {th }}$ May, 2000).

${ }^{29}$ It must be noted that we are considering only registered immigration. Rioja is said to have a higher proportion of non-registered immigrants than the rest of Spain.
}

its peak in the first decade of the XXI century. Then, in section 5, we have enlarged the analysis with some features of industrial districts. In section 6 we have explained our analytical approach of the Oenopolis, linking the performance of the wine sector to the main socioeconomic changes experienced at Rioja.

As we are referring to a specific sector and time, our approach has some limitations, such as the temporal consistency of our results or its expansion to other sectors and regions. Nevertheless, as other regions' economic welfare may be highly dependent on the structure of specific productive systems, an analytical framework like this may inspire tailor-made analysis for the different cases involved.

\section{REFERENCES}

[1] Forni G, Scienza A. 2.500 anni di cultura della vite nell'ambito alpino e cisalpino. Trento: Istituto Trentino del Vino 1996.

[2] Unwin T. El vino y la viña. Geografía histórica de la viticultura y el comercio del vino. Barcelona: Tusquets ed 2001.

[3] Roberts RD. The choice: a fable of free trade and protectionism. Upper saddle river New Jersey: Prentice Hall 2001.

[4] European Commission. Towards a sustainable European wine sector. Bruxelles: European Commission 2006.

[5] Committee of the regions. The wine sector: a driving force for regional development. Bruxelles: Deve, Committee of the Regions 2006.

[6] Gómez-Bezares F, Larreina M. An approach to the valuation of Rioja wine. J Wine Res 2008; 19(1): 33-50.

[7] Larreina M, Aguado R. Beyond the cluster: how wine drives regional economy to success. "Oenopolis" the case of Rioja. Int J Wine Buss Res 2008; 20(21): 153-70.

[8] Zanni L, Ed. Leading firms and wine clusters. Milano: Franco Angelli ed 2004.

[9] McRae-Williams P. Wine and regional tourism: strengthening complementarity to facilitate regional development. Candidature Report University of Ballarat 2002.

[10] Porter M. The competitive advantage of nations. New York: Free Press 1990.

[11] Porter M. Clusters of innovation. Regional foundation of US competitiveness. San Francisco: Council on Competitiveness 2001.

[12] Porter M. New Zealand competitiveness: the next agenda. Auckland: Catching the Knowledge Wave 2001.

[13] Alexander R, Arney R, Black N, Frost E, Shivananda A. The California wine cluster. Boston: Harvard School of Business 1997.

[14] Porter M. The California Wine Cluster. Boston: Harvard Business School 1999.

[15] Bond G. The California Wine Cluster. Boston: Harvard School of Business 2000 .

[16] Porter M. Clusters and competitiveness: findings from the cluster mapping project. Cambridge: Corporate Strategies for the Digital Economy 2001.

[17] MKF. Economic impact of California Wine 2004. Santa Helena California: MKF 2004.

[18] MKF. Economic impact of California Wine 2006. Santa Helena California: MKF 2006.

[19] Porter M, Sölvell Ö. The Australian Wine Cluster. Boston: Harvard Business School 2003.

[20] Williamson K, Wood E. The dynamics of the South African wine industry cluster: a basis for innovation and competitiveness. Working paper of the University of Cape Town Cape Town 2003.

[21] Farinelli F. Technological catch-up and learning dynamics in the Chilean wine industry. Niagara-on-the-lake: Innovation and Competitiveness In The New World Of Wine 2003.

[22] Porter M. Australian competitiveness. Sydney: Leading Minds Conference 2002.

[23] Mytelka L, Goertzen H. Learning innovation and cluster growth: a study of two inherited organizations in the Niagara Peninsula Wine Cluster Discussion Paper Series $n^{\circ}$ 2004-15. Maastricht: Institute for New Technologies United Nations University 2003. 
[24] Padmore T. Mapping the Okanagan Wine Cluster. Niagara-on-thelake: Innovation and Competitiveness in the New World of Wine 2003.

[25] García PAM, Fumero AS. Análisis estratégico comparativo de dos industrias agroalimentarias: cadena de valor y filière vitivinícola. Serie Estudios 01/43 Santa Cruz de Tenerife: Universidad de La Laguna 2001.

[26] Zampi V. Wine Management. Firenze: Centrostampa Il Prato 2003.

[27] Haines P. The Whisky Industry \& the Regional Economy: an economic analysis of imminent innovations in public policy $\mathrm{PhD}$. St. Andrews Scotland: University of St. Andrews 1998.

[28] ACIL Consultants. Pathways to profitability for small and medium wineries. Sydney: Department of Agriculture Fisheries and Forestry of Australia 2002.

[29] Foster W, Beaujanot A, Zúñiga JI. Marketing focus in the Chilean wine industry. J Wine Res 2002; 13(1): 35-42.

[30] Becattini G. Riflessioni sul distretto industriale marshalliano come concetto socioeconomico. Stato E Mercato 1989; 25: 111-28.

[31] Becattini G. Distretualità fra industria e agricoltura. La Questione Agraria 2000; 2: 9-24.

[32] Marshall A. Principles of economics: an introductory volume. London: MacMillan 1890

[33] David PA. Clio and the Economics of QWERTY. Am Econ Rev 1985; 75(2): 332-37.

[34] Krugman P. Economic integration in Europe: conceptual issues. In: Padoa-Schioppa T, Ed. Efficiency stability and equity: a strategy for the evolution of the economic system of the European community. Oxford: Oxford University Press 1987; pp. 117-40.

[35] Krugman P. Development geography and economic theory. Cambridge Massachusetts: MIT Press 1995.
[36] Pascual CJ. El vino de Rioja. Calidad originalidad y prestigio histórico. Logroño: Ediciones La Prensa del Rioja, 2003.

[37] Larreina M, Tolosa L. Vinos y bodegas de Rioja. Barcelona: LT \& A Ediciones 2005.

[38] OIV. State of vitiviniculture world report. Paris: Office International de la Vigne et du Vin 2009.

[39] Gómez-Bezares F. Plan Estratégico del Vino de Rioja 2005-2020. La prensa del Rioja 2005; 160: 10-4.

[40] Mora P, Castaing Y. Bonnes pratiques dans le marketing du vin, ed. Paris: Dunod-La Vigne 2005.

[41] Datz C. Wine \& Design, ed. Kempen: Te Neues 2007.

[42] Nonaka I. The knowledge-creating company. Harvard Buss Rev 1991; 69: 96-104.

[43] Castriota S, Delmastro M. The economics of collective reputation: minimum quality standards vertical differentiation and optimal group size. Working Paper Universitá di Torento, Torento 2009.

[44] Intercampo. Sentimiento regional en La Rioja. Logroño: report for the Gobierno de La Rioja 2004.

[45] Wine Intelligence. Notoriedad y hábitos de consumo del vino español en los principales mercados de exportación. Madrid: Observatorio Español del Mercado del Vino 2009.

[46] Hubrich K. Regional inflation dynamics within and across euro area countries and a comparison with the United States. ECB Res Bull 2008; 7: 7-10.

[47] Larreina M, Gomez-Bezares F. El vino Rioja como explicación de las peculiaridades de la inflación riojana. Estudios Empresariales 2004; 116: 60-73.

[48] INE. Encuesta Continua de Presupuestos Familiares. Madrid: INE 2006.

(c) Larreina et al.; Licensee Bentham Open.

This is an open access article licensed under the terms of the Creative Commons Attribution Non-Commercial License (http://creativecommons.org/licenses/by$\mathrm{nc} / 3.0 /$ ) which permits unrestricted, non-commercial use, distribution and reproduction in any medium, provided the work is properly cited. 